\title{
Standardization and Sensory evaluation of Sattu-Mantha: A traditional energy drink
}

\author{
Research Article
}

\section{Preetpal Singh $^{*}$, Hitesh Vyas², Ashvinee Vasava ${ }^{1}$, Dharmik Vasani1 ${ }^{1}$, Sunny Patil ${ }^{1}$}

1. Ph.D Scholar, 2. Professor,

Department of Basic Principles, ITRA Jamnagar, Gujarat, India.

\begin{abstract}
Background: Sattu is a traditional and well known functional food in India. It is consumed as a refreshing drink during summers. In Ayurveda, Sattu has been described as Saktu. According to classical texts of Ayurveda, Powder of roasted and dehusked Yava (barley) is known as Saktu. Liking and disliking for any food article depends on senses of consumer. For deciding the consumer's choice toward the food products, sensory parameters followed by the nutritional properties are required to be considered. Aim and objectives: To standardize recipe of Sattu-Mantha and sensory evaluation of Sattu-Manha. Material and methods: In present study, sensory evaluation of Yava (Barley) Sattu prepared by two different methods has been carried out. Sattu was served in the form of Mantha. In this study scoring for different sensory parameters was done by using 9-point Hedonic scale (Lawless and Klein, 1991). Results and Conclusion: On the bases of scores given to different sensory parameters, Sattu-Mantha prepared by both the methods is accepted by assessors but Sattu-Mantha prepared by using sugar powder was much liked by assessors as compared to Sattu-Mantha prepared by using Jaggery powder.
\end{abstract}

Key Words: Mantha, Sattu, Sensory-evaluation, Yava (Barley).

\section{Introduction}

Sattu is a traditional food in India. It is roasted pulse or cereal flour and used as ready - to - eat (RTE) snack food in northern parts of India, particularly in rural areas (1). It is traditionally prepared from either roasted cereal particularly barley, maize or roasted bengal gram or combination of these. It is consumed as a refreshing drink during summers.

In Ayurveda, Sattu has been described as Saktu and its medicinal properties have been mentioned in different lexicons of Ayurveda. According to classical texts of Ayurveda, Powder of roasted and dehusked Yava (barley) is known as Saktu (2). While Acharya Bhavaprakash stated that powdered form of any roasted Dhanya (cereals/grains/corn) is known as Saktu (3). Saktu can be made by roasted Chanaka (Bengal grams) Yava (barley) and Shali (a variety of rice) (4). In addition to these, Kaidev Nighantu have also explained the properties of Saktu made by Badar and Karkandhu (Varieties of Jujube) (5).

Sattu/Saktu is dry in nature, aggravates Vata, increases fecal matter and regulate peristalsis. When consumed, it immediately nourishes and strengthens the consumer (6). When Sattu is taken in the form of

\section{* Corresponding Author:}

\section{Preetpal Singh}

Ph.D. Scholar,

Department of Basic Principles,

ITRA Jamnagar,

Gujarat. India. 361008

Email Id: singhpreet523@gmail.com
Mantha, it provides instant strength, overcome thirst and fatigue (7).

As Sattu is a well known functional food, satisfying the demands of the consumers is a major issue in order to succeed in promoting the consumption of functional food products. For deciding the consumer choice towards the food products, sensory parameters followed by the nutritional properties are required to be considered. Due to this reason, sensory analysis of any developed food product is an important concern prior to supply the product in the market or to the consumers (8). Knowledge gained through individual sensation is the key parameter for the evaluations in any field. But in case of sensory evaluation, it is very problematic to model and manage the knowledge gained by sensation. It is due to the fact that involvement of uncertainty and imprecision in case of acquiring information by human senses makes it difficult for the evaluation of the sensory data (9).

Scientists have developed different scoring scales for getting certainty in the results of sensory evaluation, 9-point hedonic scale is one of these scales. In the present study we have used 9-point hedonic scale for scoring of different sensory parameters like appearance, color, odour etc.

\section{Aim and Objectives}

- To develop GMP (good manufacturing practice) and standardize the recipe of Sattu-Mantha.

- To compare acceptability and palatability of SattuMantha prepared by using two different methods with 9-point Hedonic scale. 


\section{Materials and Methods}

Procurement of materials

Seeds of barley (Yava), ghee and sugar powder were procured from local market of Jamnagar and jaggery was procured from an organic farm.

\section{Preparation of barley (Yava) Sattu}

Barley seeds were cleaned and then roasted in hot sand with continuous stirring. Then Roasted barley seeds were milled and sieved through sieve no. 72 (10).

\section{Development of ready mix}

Many initial trials were conducted to test combination of different proportions of roasted barley powder, ghee, sugar powder/jaggery powder and water. Then following proportions of roasted barley powder, ghee, sugar powder/jaggery powder and water were finalized for sensory evaluation

\section{Sample-A:}

- Roasted Yava powder - 20 gms

- Ghee - $10 \mathrm{ml}$

- Jaggery powder- 10gms

- Water $-150 \mathrm{ml}$

\section{Sample-B:}

- Roasted Yava powder - 20 gms

- Ghee - $10 \mathrm{ml}$

- Sugar powder- 10gms

- Water - $150 \mathrm{ml}$

\section{Method of Sattu-Mantha preparation for consumption}

According to classical texts of ayurveda, appropriate amount of ghee to be mixed with Sattu powder then cold water should be added up to the consistency neither too thick nor too thin liquid to consume it (11).

In present study for every sample 20 grams roasted yava powder was properly mixed manually with $10 \mathrm{ml}$ of ghee. After that for sample-A, 10 grams jaggery powder and $150 \mathrm{ml}$ water were added to powdered Sattu and it was shaken well in hand shaker.
For sample-B, in the place of jaggery powder, 10 grams sugar powder and $150 \mathrm{ml}$ water were added to powdered Sattu and shaken well in shaker to mix it properly.

\section{Sensory evaluation of Sattu-Mantha prepared from two different methods:}

When the quality of food products is assessed by means of human sensory organs, the evaluation is said to be sensory or subjective or organoleptic. Every time when food is eaten, a judgment is made. Sensory evaluation consists of judging the quality of food by a panel of assessors. For this study assessment was done by using 9-point Hedonic scale (Lawless and Klein, 1991) for different parameters.

A panel of assessors consisting of 09 teaching staff, including head of Basic Principles Department, ITRA Jamnagar and 42 Post-graduation and Ph.D scholars of ITRA Jamnagar were selected randomly. Acceptability and organoleptic scoring of the preparations was done on the basis of the scores given by the assessors. The recipes were prepared in the college premises. The recipes were evaluated for

- Appearance

- Color

- Odour

- Flavor

- Consistency

- Mouth-feel (palatability)

- Adhesiveness

The following points were taken in to consideration - The assessors were not allowed to enter the preparation area, as they could gain information which could influence their judgment.

- They were not allowed to consult each other, but were asked to give unbiased opinion.

- The assessors were provided with a glass of water each for oral revising between the samples.

- Time intervals between the samples were kept constant.

\section{Scoring scales for different sensory parameters}

Image 1: Appearance

\begin{tabular}{ccccccccc}
\hline & & & & & $\mid$ & $\mid$ & $\mid$ & \\
$\mathbf{1}$ & $\mathbf{2}$ & $\mathbf{3}$ & $\mathbf{4}$ & $\mathbf{5}$ & $\mathbf{6}$ & $\mathbf{7}$ & $\mathbf{8}$ & $\mathbf{9}$ \\
$\begin{array}{c}\text { Extremely } \\
\text { Bad }\end{array}$ & $\begin{array}{c}\text { very much } \\
\text { bad }\end{array}$ & $\begin{array}{c}\text { moderately } \\
\text { bad }\end{array}$ & $\begin{array}{c}\text { slightly } \\
\text { bad }\end{array}$ & $\begin{array}{c}\text { Neither bad } \\
\text { Nor good }\end{array}$ & $\begin{array}{c}\text { slightly } \\
\text { good }\end{array}$ & $\begin{array}{c}\text { moderately } \\
\text { good }\end{array}$ & $\begin{array}{c}\text { very } \\
\text { good }\end{array}$ & excellent
\end{tabular}

Image 2: Color

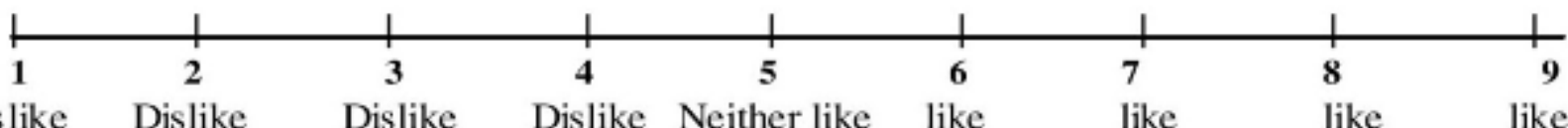

Extremely very much moderately slightly Nor Dislike slightly moderately very much extremely 


\section{Image 3: Odour}

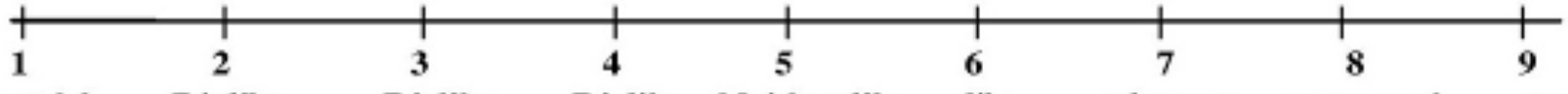

rejectable Dislike Dislike Dislike Neither like like pleasant very much extremely very much moderately slightly Nor Dislike slightly pleasant pleasant

\section{Image 4: Flavour}

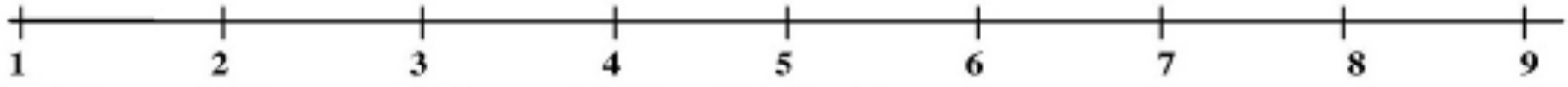

rejectable Dislike Dislike Dislike Neither like like pleasant very much extremely very much moderately slightly Nor Dislike slightly pleasant pleasant

\section{Image 5: Consistency}

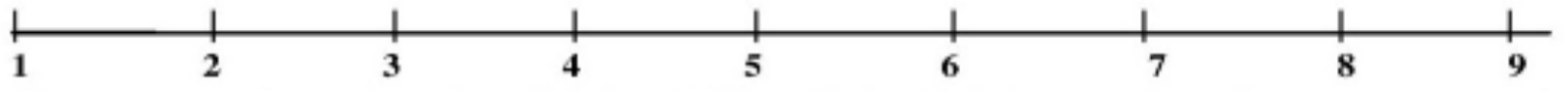

Thin like very much moderately slightly Neither thick slightly moderately very semisolid

water thin thin thin Nor thin thick thick

\section{Image 6: Mouth-feel (Palatability)}

\begin{tabular}{|c|c|c|c|c|c|c|c|c|}
\hline & 1 & 1 & 1 & L & 1 & 1 & l & 1 \\
\hline 1 & 2 & 3 & 4 & 5 & 6 & 7 & 8 & 9 \\
\hline tabl & $\begin{array}{c}\text { Dis like } \\
\text { very much }\end{array}$ & $\begin{array}{c}\text { Dislike } \\
\text { moderately }\end{array}$ & $\begin{array}{l}\text { Dislike } \\
\text { slightly }\end{array}$ & $\begin{array}{l}\text { Neither like } \\
\text { Nor Dislike }\end{array}$ & $\begin{array}{c}\text { like } \\
\text { slightly }\end{array}$ & pleasant & $\begin{array}{r}\text { very much } \\
\text { pleasant }\end{array}$ & $\begin{array}{l}\text { extremely } \\
\text { pleasant }\end{array}$ \\
\hline
\end{tabular}

Image 7: Adhesiveness

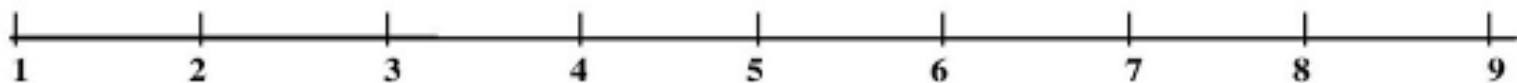

Extremely very much moderately slightly neithersticky less moderately extremely non-sticky et al sticky sticky sticky sticky nor non-sticky sticky less sticky less sticky

\section{Observations and Results}

Table 1: Score of two samples for Appearance

\begin{tabular}{|l|l|l|l|l|l|l|l|l|l|} 
& $\begin{array}{l}\text { Extremely } \\
\text { bad }\end{array}$ & $\begin{array}{l}\text { Very } \\
\text { much bad }\end{array}$ & $\begin{array}{l}\text { Moderately } \\
\text { bad }\end{array}$ & $\begin{array}{l}\text { Slightly } \\
\text { bad }\end{array}$ & $\begin{array}{l}\text { Neither } \\
\text { bad nor } \\
\text { good }\end{array}$ & $\begin{array}{l}\text { Slightly } \\
\text { good }\end{array}$ & $\begin{array}{l}\text { Moderately } \\
\text { good }\end{array}$ & Very good & Excellent \\
\hline Sample-A & 0 & 0 & 0 & 1 & 0 & 11 & 10 & 27 \\
\hline Sample-B & 0 & 0 & 0 & 1 & 1 & 6 & 12 & 23 & 8 \\
\hline
\end{tabular}

Maximum scores for appearance were in $8^{\text {th }}$ column i.e. very good for both the samples followed by $6^{\text {th }}$ i.e slightly good for group A and 7th i.e. moderately good for sample B.

\section{Table 2: Score of two samples for Color}

\begin{tabular}{|l|c|c|c|c|c|c|c|c|c|} 
& $\begin{array}{c}\text { Dislike } \\
\text { extremely }\end{array}$ & $\begin{array}{c}\text { Dislike } \\
\text { very } \\
\text { much }\end{array}$ & $\begin{array}{c}\text { Dislike } \\
\text { moderately }\end{array}$ & $\begin{array}{c}\text { Dislike } \\
\text { slightly }\end{array}$ & $\begin{array}{c}\text { Neither } \\
\text { like nor } \\
\text { dislike }\end{array}$ & $\begin{array}{c}\text { Like } \\
\text { slightly }\end{array}$ & $\begin{array}{c}\text { Like } \\
\text { moderately }\end{array}$ & $\begin{array}{c}\text { Like } \\
\text { very } \\
\text { much }\end{array}$ & $\begin{array}{c}\text { Like } \\
\text { extremely }\end{array}$ \\
\hline Sample-A & 0 & 0 & 0 & 1 & 0 & 5 & 19 & 22 & 4 \\
\hline Sample-B & 0 & 0 & 0 & 1 & 1 & 2 & 18 & 23 & 6 \\
\hline
\end{tabular}

Maximum scores for color were in $8^{\text {th }}$ column i.e. like very much for both the samples followed by 7 th i.e like moderately for both the samples. 
Table 3: Score of two samples for Odour

\begin{tabular}{|l|c|c|c|c|c|c|c|c|c|} 
& Rejectable & $\begin{array}{c}\text { Dislike } \\
\text { very } \\
\text { much }\end{array}$ & $\begin{array}{c}\text { Dislike } \\
\text { moderately }\end{array}$ & $\begin{array}{c}\text { Dislike } \\
\text { slightly }\end{array}$ & $\begin{array}{c}\text { Neither } \\
\text { like nor } \\
\text { dislike }\end{array}$ & $\begin{array}{c}\text { Like } \\
\text { slightly }\end{array}$ & $\begin{array}{c}\text { Pleasant } \\
\begin{array}{c}\text { Very } \\
\text { much } \\
\text { pleasant }\end{array}\end{array} \begin{array}{c}\text { Extemely } \\
\text { pleasant }\end{array}$ \\
\hline Sample-A & 0 & 0 & 0 & 0 & 0 & 5 & 33 & 10 & 3 \\
\hline Sample-B & 0 & 0 & 0 & 0 & 2 & 6 & 18 & 21 & 4
\end{tabular}

Maximum scores for odour, for sample A were in $7^{\text {th }}$ column i.e. pleasant and for sample B were in $8^{\text {th }}$ column i.e. very much pleasant followed by score in $8^{\text {th }}$ column i.e. very much pleasant for group A and score in $7^{\text {th }}$ column i.e. pleasant for group B.

\section{Table 4: Score of two samples for Flavour}

\begin{tabular}{|l|c|c|c|c|c|c|c|c|c|} 
& Rejectable & $\begin{array}{c}\text { Dislike } \\
\text { very } \\
\text { much }\end{array}$ & $\begin{array}{c}\text { Dislike } \\
\text { moderately }\end{array}$ & $\begin{array}{c}\text { Dislike } \\
\text { slightly }\end{array}$ & $\begin{array}{c}\text { Neither } \\
\text { like nor } \\
\text { dislike }\end{array}$ & $\begin{array}{c}\text { Like } \\
\text { slightly }\end{array}$ & Pleasant & $\begin{array}{c}\text { Very } \\
\text { much } \\
\text { pleasant }\end{array}$ & $\begin{array}{c}\text { Extemely } \\
\text { pleasant }\end{array}$ \\
\hline Sample-A & 0 & 0 & 0 & 1 & 0 & 12 & 20 & 13 & 5 \\
\hline Sample-B & 0 & 0 & 0 & 0 & 0 & 7 & 12 & 27 & 5 \\
\hline
\end{tabular}

Maximum scores for flavour, for sample A were in $7^{\text {th }}$ column i.e. pleasant and for sample B were in $8^{\text {th }}$ column i.e. very much pleasant followed by score in $8^{\text {th }}$ column i.e. very much pleasant for group A and score in $7^{\text {th }}$ column i.e. pleasant for group B.

Table 5: Score of two samples for Consistency

\begin{tabular}{|l|c|c|c|c|c|c|c|c|c|}
\hline & $\begin{array}{c}\text { Thin like } \\
\text { water }\end{array}$ & $\begin{array}{c}\text { Very } \\
\text { much } \\
\text { thin }\end{array}$ & $\begin{array}{c}\text { Moderately } \\
\text { thin }\end{array}$ & $\begin{array}{c}\text { Slightly } \\
\text { thin }\end{array}$ & $\begin{array}{c}\text { Neither } \\
\text { thick nor } \\
\text { thin }\end{array}$ & $\begin{array}{c}\text { Slightly } \\
\text { thick }\end{array}$ & $\begin{array}{c}\text { Moderatley } \\
\text { thick }\end{array}$ & $\begin{array}{c}\text { Very } \\
\text { thick }\end{array}$ & Semisolid \\
\hline Sample-A & 0 & 0 & 2 & 1 & 34 & 11 & 3 & 0 & 0 \\
\hline Sample-B & 0 & 0 & 2 & 7 & 23 & 16 & 3 & 0 & 0 \\
\hline
\end{tabular}

Maximum scores for consistency were in $5^{\text {th }}$ column i.e. neither thick nor thin for both the samples followed by score in $6^{\text {th }}$ column i.e slightly thick for both the samples.

Table 6: Score of two samples for Mouth-feel (palatability)

\begin{tabular}{|l|c|c|c|c|c|c|c|c|c|}
\hline & Rejectable & $\begin{array}{c}\text { Dislike } \\
\text { very } \\
\text { much }\end{array}$ & $\begin{array}{c}\text { Dislike } \\
\text { moderately }\end{array}$ & $\begin{array}{c}\text { Dislike } \\
\text { slightly }\end{array}$ & $\begin{array}{c}\text { Neither } \\
\text { like nor } \\
\text { dislike }\end{array}$ & $\begin{array}{c}\text { Like } \\
\text { slightly }\end{array}$ & Pleasant & $\begin{array}{c}\text { Very } \\
\text { much } \\
\text { pleasant }\end{array}$ & $\begin{array}{c}\text { Extemely } \\
\text { pleasant }\end{array}$ \\
\hline Sample-A & 0 & 0 & 0 & 0 & 1 & 10 & 26 & 11 & 3 \\
\hline Sample-B & 0 & 0 & 0 & 1 & 0 & 5 & 15 & 24 & 6 \\
\hline
\end{tabular}

Maximum scores for mouth-feel (palatability), for sample A were in $7^{\text {th }}$ column i.e. pleasant and for sample B were in $8^{\text {th }}$ column i.e. very much pleasant followed by score in $8^{\text {th }}$ column i.e. very much pleasant for group A and score in $7^{\text {th }}$ column i.e. pleasant for group B.

Table 7: Score of two samples for Adhesiveness

\begin{tabular}{|l|c|c|c|c|c|c|c|c|c|} 
& $\begin{array}{c}\text { Extremely } \\
\text { sticky }\end{array}$ & $\begin{array}{c}\text { Very } \\
\text { much } \\
\text { sticky }\end{array}$ & $\begin{array}{c}\text { Moderately } \\
\text { sticky }\end{array}$ & $\begin{array}{c}\text { Slightly } \\
\text { sticky }\end{array}$ & $\begin{array}{c}\text { Neither } \\
\text { sticky nor } \\
\text { sticky }\end{array}$ & $\begin{array}{c}\text { Less } \\
\text { sticky }\end{array}$ & $\begin{array}{c}\text { Moderately } \\
\text { sticky }\end{array}$ & $\begin{array}{c}\text { Extremely } \\
\text { less sticky }\end{array}$ & $\begin{array}{c}\text { Non-sticky } \\
\text { at al }\end{array}$ \\
\hline Sample-A & 0 & 0 & 0 & 1 & 0 & 11 & 10 & 27 & 2 \\
Sample-B & 0 & 0 & 0 & 1 & 1 & 6 & 12 & 23 & 8 \\
\hline
\end{tabular}

Maximum scores for adhesiveness were in $5^{\text {th }}$ column i.e. neither sticky nor non-sticky for both the samples followed by $6^{\text {th }}$ i.e slightly sticky for both the samples.

Table: 8 Average score of two samples for different parameters

\begin{tabular}{|l|r|r|r|r|r|r|r|r|}
\hline Sample & \multicolumn{2}{|c|}{ Appearance } & Colour & Odour & Flavour & Consistency & Mouth-feel & Adhesiveness \\
\hline Sample-A & 7.35 & 7.43 & & 7.21 & 7.15 & 5.15 & 7.09 & 6.52 \\
\hline Sample-B & 7.54 & 7.54 & & 7.37 & 7.58 & 5.35 & 7.54 & 6.45 \\
\hline
\end{tabular}
table-8.

The average scores of different parameters selected for sensory evaluation of Sattu-Mantha are given in

From the observations on different sensory parameters, it was observed that, $52.94 \%$ assessors found very good appearance for sample-A and $45.09 \%$ for sample-B. On the bases of scores given to the color, $43.13 \%$ assessors liked sample-A very much and $45.09 \%$ assessors liked sample-B very much. According to $64.70 \%$ assessors, odour of sample-A is pleasant and odour of sample-B is very much pleasant according to
$41.17 \%$ assessors. In case of flavor for sample-A, $39.21 \%$ assessors found it pleasant and for sample-B $52.94 \%$ assessors found it very much pleasant. Neither thick nor thin consistency was observed by $66.66 \%$ assessors for sample-A and by $45.09 \%$ assessors for sample-B. In case of mouth-feel parameter $50.98 \%$ assessors found sample-A pleasant and $47.05 \%$ assessors found sample-B very much pleasant. In the 
evaluation of adhesiveness $27.45 \%$ and $25.49 \%$ assessors found neither sticky nor non-sticky adhesiveness for sample-A and B respectively.

\section{Conclusion}

In present study Sattu-Mantha prepared by both the methods are accepted by assessors. On the basis of individual scores of different parameters sample-B was much liked by assessors as compared to sample-A i.e Sattu-Mantha prepared using sugar powder is more suitable as compared to Sattu-Mantha prepared using Jaggery powder.

\section{Author's note}

Hitesh Vyas and Preetpal Singh: Preparation of study design, supervising, performing and co-ordinating the study, collecting data, analyzing data, drafting and submitting the manuscript. Ashvinee Vasava, Dharmik Vasani, and Sunny Patil: Supported in preparation of Sattu-Mantha.

\section{References}

1. Deshpande et. al. Enhancing the Nutritive Value of Barley Based Sattu by Soy Fortification, The Indian Journal of Nutrition and Dietetics, April 2004; 41(4); 146-159

2. Sastri HS, editor, Astangahrdaya of Vagbhata, Ayurved Rasayana teeka, Reprint edition, Varanasi; Chaukhamba Sanskrit Sansthan, 2016, 93p
3. Pandey GS, editor, Bhavaprakasha of Bhavamishra, enlarged edition, Varanasi; Chaukhambha Bharti Academy, 2010, 727p

4. Pandey GS, editor, Bhavaprakasha of Bhavamishra, enlarged edition, Varanasi; Chaukhambha Bharti Academy, 2010, 727-728p

5. Sharma Priyavrata, editor \& translator, Kaidev Nighantu, reprint edition, Varanasi; Chaukhambha orientalia, 2016, 431p

6. Acharya YT, editor. Charakasamhita of Agnivesha, Reprint edition, Varanasi: Chaukhamba Orientalia; 2016, 168p

7. Acharya YT, editor. Susruta Samhita of Susruta, Reprint edition, Varanasi: Chaukhamba Orientalia; 2016, 241p

8. Routray and Mishra, Scientific and Technical Aspects of Yogurt Aroma and Taste: A Review, Comprehensive Reviews in Food Science and Food Safety, 2011; 10; 208-220

9. Martinez et .al. Sensory evaluation based on linguistic decision analysis, International Journal of Approximate Reasoning ; 2007; 44(2); 148-164.

10. Sastri HS, editor, Astangahrdaya of Vagbhata, Ayurved Rasayana teeka, Reprint edition, Varanasi; Chaukhamba Sanskrit Sansthan, 2016, 93p.

11. Acharya YT, editor. Susruta Samhita of Susruta, Reprint edition, Varanasi: Chaukhamba Orientalia; 2016, 241p. 